\title{
Comment on Richard Tremblay: The development of youth violence: An old story with new data
}

\author{
Ross Homel \\ Professor of Criminology and Criminal Justice \\ Griffith University \\ Australia
}

Published as:

Homel, R. (2007). Comment on Richard Tremblay: The development of youth violence: An old story with new data. European Journal on Criminal Policy and Research 13:175-177

In a series of longitudinal studies and papers over a period of many years Richard Tremblay has presented persuasive evidence that preschool children are not the 'innocents' portrayed by Rousseau and by his precursors and successors in much Western philosophy and literature. Aggressive behaviour is not, it seems, simply learned in adolescence but has a strong degree of continuity with aggression in early childhood. Indeed, as Richard observes, “... there is more to the weakling's aggressions than the disciples of Rousseau could imagine" (p. X).

Since chronic physical aggression manifests so early in life, Richard suggests that the preschool years provide the "best window of opportunity" for intervention. In particular, he is an advocate of quality preschool education to support the efforts of families to make young children fit for society. Preschools can, for example, contribute greatly to the development of children's capacity to cooperate, to wait their turn, to delay gratification, and to use language skills rather than aggression to have their needs met. 
This is a policy agenda with which I am in wholehearted agreement, although I want to argue that it is incomplete unless placed within a life course and social contextual framework. I draw from my own experience and that of my colleagues in designing, implementing and evaluating the Pathways to Prevention Project in a disadvantaged area of Brisbane (Freiberg et al., 2005; Homel et al., 2006), as well as the work of my developmental psychologist colleagues who worry about an over-emphasis on the early years (e.g., Goodnow, in press; Hayes, in press).

The first phase of the Pathways Project, which is an ongoing partnership between Griffith University and the national community organization Mission Australia, was focused on the transition to school in one of the most disadvantaged urban areas in Queensland. It combined child-focused programs delivered through state preschools (with an emphasis on communication/ language and social skills) with a range of services for families, within a community development framework. It therefore involved four-year old children, their families, local schools, and the ethnic communities of which they are a part.

The early results have been encouraging, particularly the improvements in teacherrated child behaviour over the preschool year in the intervention classes compared with the controls. What we consider especially important however is the fact that outcomes were best for those children who participated in the preschool program and whose parents participated in some aspect of the family program. Moreover, as we have continued our work in partnership with the schools into the primary years we have come to understand more fully the intricate links between family, school and 
community contexts and the critical importance of institutional and community structures that help sustain early positive development.

It is against this background that I have given considerable thought to the final sentence in Richard's paper. Speaking from the longitudinal perspective that reveals the interconnectedness of child pathologies and their devastating consequences over time for the child and the wider community, Richard concludes that "... failure to teach children to regulate violent behaviour during the early years leads to poverty much more clearly than poverty leads to violence" (p. X).

What I think is obscured in this conclusion is the fact that the process of teaching young children to regulate violent behaviour is far more difficult in poor than in welloff communities because parents and schools are faced with immensely greater barriers in achieving their goals of socialization and the provision of safe, nurturing and loving environments than their counterparts in more privileged suburbs. Our experience is that poverty does clearly lead to violence because the conditions for making human beings human are constantly being eroded by the "ecological conspiracies" that undermine the efforts of parents, teachers, community leaders, and helping agencies.

As I have observed elsewhere (Homel, 2005; 2006) the problem is not that parents in poor communities don't care and that they don't do their best to keep an eye on their children, it's that they are beset by such huge daily demands and challenges economic, emotional, social - that they sometimes can't give children the time, energy, and attention they need. We have catalogued these processes in exhaustive 
detail in a series of case studies in the report on the project's first five years (Homel et al., 2006). Instead of a catalogue of statistical variables that mostly refer to deficiencies in children or in their families, we think in terms of the resources needed for parents and their communities to overcome the barriers or solve the problems that they face on a daily basis in their child rearing efforts, and we contrast these with the resources actually available to them to do their job.

In other words, the issue is a lack of fit between the resources needed and those available, rather than deficits in individual people or families. The challenge is to open new doors or force open half-shut doors for families and children doing it tough, not focus exclusively on the "problem child". Thus we have come to understand negative developmental pathways as much in terms of system responses - and their deficiencies - as in terms of individual or family pathology. And it is these systems that will tend to erode the benefits of even the best early-in-life interventions unless their deficiencies are understood and remedied (Hayes, in press).

This is the large research, policy and practice agenda that we have now embarked on. It is, I believe, totally compatible with an early years agenda, especially in Englishspeaking countries where historically the early years have been viewed as a private domain and starved of public resources. The early years are an extremely important foundation for positive development and from my perspective as an Australian we can hardly focus too much on them, especially in disadvantaged regions. To its great credit the Australian Government has begun in recent years to invest heavily in just this way through its Stronger Families and Communities Strategy ${ }^{\mathrm{i}}$. 
However, the early years agenda on its own will never create the healthier, fairer and less violent society envisaged by its proponents. What is needed in addition is the ecological-life course perspective of the kind I have adumbrated, with an emphasis on the creation of sustaining institutions and 'child friendly' communities that will support the endeavours of families and schools to turn the aggressive, brawling, selfish infant into people like us!

So we can in good conscience and with good reason follow Richard's advice. However, let us also attend to the organisational, structural and community impediments to the maintenance over the life course of the positive benefits of interventions in the early years, especially in poor communities where continuities in adverse circumstances may explain as much about the persistence of aggressive behaviours as individual factors like a lack of capacity for self-control. Let us also be alive to the importance of creating, in Jacqueline Goodnow's words, "recovery pathways" when things go wrong for older children. Forcing open doors shut by unresponsive systems on behalf of out-of-control ten year olds may be as important as laying strong foundations in the early years. We need to find out.

\section{References}

Freiberg, K., Homel, R., Batchelor, S., Carr, A., Lamb, C., Hay, I., Elias, G. \& Teague, R. (2005). Creating pathways to participation: A community-based developmental prevention project in Australia. Children and Society, 19: 144-157.

Goodnow, J. (in press). Adding social contexts to developmental analysis of crime prevention. Australian and New Zealand Journal of Criminology, 39. 
Hayes, A. (in press). Why early in life is not enough: Timing and sustainability in early intervention and prevention. In Alan France and Ross Homel (Eds.), Pathways and crime prevention: Theory, policy and practice. Cullompton, UK: Willan Publishers.

Homel, R. (2005). Developmental crime prevention. In Nick Tilley (Ed.), Handbook of crime prevention and community safety (pp. 71-106). Cullumpton, Devon, UK: Willan Publishing.

Homel, R. (2006). As if children mattered ... Lecture presented to the Brisbane Ideas Festival, April 2, 2006. http://www.griffith.edu.au/centre/kceljag/

Homel, R., Freiberg, K., Lamb, C., Leech, M., Hampshire, A., Hay, I., Elias, G., Carr, A., Manning, M., Teague, R. \& Batchelor, S. (2006). The Pathways to Prevention Project: The First Five Years, 1999-2004. Sydney: Griffith University \& Mission Australia

\footnotetext{
${ }^{\mathrm{i}}$ http://www.facs.gov.au/internet/facsinternet.nsf/aboutfacs/programs/sfsccommunities_for_children.htm
} 